International Journal of English Literature and Social Sciences
Vol-6, Issue-1; Jan-Feb, 2021
Journal Home Page Available: https://ijeab.com/
Journal DOI: $10.22161 /$ ijels

\title{
Ways of Looking: Male Gaze in Henrik Ibsen's When We Dead Awaken
}

\author{
Arjun Dev Bhatta
}

\author{
Ph.D., Tri-Chandra Campus, Kathmandu, Nepal
}

Received: 28 Nov 2020; Received in revised form: 01 Feb 2021; Accepted: 18 Feb 2021; Available online: 28 Feb 2021

(C)2021 The Author(s). Published by Infogain Publication. This is an open access article under the CC BY license

(https://creativecommons.org/licenses/by/4.0/).

\begin{abstract}
This article is an attempt to study Henrik Ibsen's drama 'When We Dead Awaken' from the point of view of male gaze theory. It reveals that exposition of women's body in nudity as an art is another form of male exploitation of female. In this environment, a woman becomes source of pleasure for males who gaze women to fulfill their erotic desires. In doing so, this article explores how a woman loses her identity and individuality in male dominated society that evaluates and defines woman as a sexual object.
\end{abstract}

Keywords - Male gaze, voyeurism, nudity, exploitation, objectification, visual pleasure, resurrection.

\section{INTRODUCTION}

The most influential modern dramatist Henrik Ibsen has exposed male female relationship inside and outside home. Human relationship, from the time immemorial, is based on male/female binary which prioritizes male as subject and denigrates female as an object. In this asymmetry, males posit themselves at the center whereas females remain marginal and subdued. Women are judged and defined as helpmate, sex object, source of luxury and property. Women's body and physical beauty becomes source of pleasure and inspiration for males. In this situation, women have been victim of male gaze and remained so throughout history. This is the real picture Ibsen presents in a realistic manner in his plays. For Ibsen, woman can be a universal tragic heroine. His realistic plays fulfill the urgent need of the real presence of women's bodies onstage. As a father of realism, and founder of modernism in the theatre, he exposes familial and social issues and everyday life. In this mode of presentation, he lets his characters speak and show the real situations the real people face in the society as its members. Regarding the nature of his plays he speaks:

The illusion I wished to produce was that of reality. I wished to leave of the readers' mind the impression that what he had read had actually happened ... My desire was to depict human beings and therefore I would not make themselves speak the language of gods (qtd. in William Raymond 40).

Ibsen was writing at the time when women, to a certain extent, imprisoned inside a house, limited to domestic chores and faced certain restriction enforced by male dominated culture. Their identity was limited to male ways of seeing either as weaker sex, submissive and frail, or as beauty, source of enjoyment and luxury. Female beauty was romanticized as per male desire. Ibsen's present play When We Dead Awaken can be studied in terms of male gaze and its effect on woman. This paper focuses how the male character, Professor Rubek achieves universal fame at the expense of Irena, his model, and treats Maia, his wife. The central character Irena is admired for her purity, carnal beauty and innocence. She falls under control of Rubek's gaze and only exists for visual pleasure. However, she enthusiastically acts as inspiration for Rubek to act. But the truth is that she is objectified, and treated as an object, not a real human being. Irena, later, gets the knowledge, and realizes that the essential power of her body has been constantly underestimated by Rubek under the presser of idealizing system. 
In the article, I have analyzed the role and character of Professor Rubek, Irena and Maia on the conceptual frameworks developed by the critics such as Laura Mulvey, John Berger, Robert Schultz, and Edward Snow.

\section{THEORETICAL PERSPECTIVE}

Gaze is simply concerned with the act of seeing and an act of being seen. According to Jeremy Hawthorn the gaze is an interpersonal looking, interactive two way process. However, it is away from a neutral process of information gathering, but has socio-cultural implications such as class, sexuality and economics. In her article 'Theories of the Gaze', She says, "Looking is not a matter of gathering information; it also signals complicity in or opposition to unequal power relationship in our world (517). She sees male gaze as the product of patriarchy that is based on dominance and power and this gendered relation to the gaze is both "the product of patriarchy and also a way of reinforcing male dominance" (513). In 'Practices of Looking: An Introduction to Visual Culture', Marita Sturken and Lisa Cartwright define: "The gaze is conceptually integral to systems of power, and to ideas about knowledge; that is to practice the gaze is to enter a personal relationship with the person being looked at" (94). In this sense, gaze can be seen as an interaction between different forms of literal and metaphorical looking.

In her founding essay 'Visual Pleasure and Narrative Cinema', the film critic Laura Mulvey draws issues of sexual difference highly dominated in Hollywood film. She claims, "Film reflects, reveals and even plays on the straight, socially established interpretation of sexual difference which controls, images, erotic ways looking and spectacle" (57). She also develops concept of male gaze as a feature of gender power asymmetry in film. She claims Hollywood films played to the models of voyeurism and scopophilia, and women are objectified because majority of heterosexual men are dominating cinema. Male gaze undermines women's human identity, relegating them to the status of object to be admired only for physical appearance. Gender asymmetry is a controlling force in cinema and constructed for the pleasure and masculine scopophilia of the male viewer which is deeply rooted in patriarchal ideologies and discourses. Mulvey constitutes that the film industry has adopted narcissistic way of portraying women as object for men, and women became "bearer of meaning, not maker of meaning" (58). She further states, "the man controls the film fantasy and also emerges as the representative of power (...) as the bearer of the look of the spectator" (qtd. in Ingrid Lewis and Irena Globan 131).
Supporting Laura's view, Ingrid and Irena state, "Film and media in general, play a significant role in shaping the value system within a culture defining the cannons of femininity, morality and beauty" (130). In this condition, a woman merely becomes an erotic figure to fulfill male fantasies, and "pleasure-giving fetish object" (Robert Schultz 368) in a male prerogative culture. Mulvey further writes:

Pleasure in looking has been split between active/male and passive/female. The determining male gaze projects its fantasy on the female figure. . . In their traditional exhibitionist role women are simultaneously looked at and displayed, with their appearance coded for strong visual and erotic impact so that they can be said to connote to-be-lookedat-ness (62).

In feminist theory, the male gaze is the act of depicting women and the world, in the visual arts and in literature from the masculine and heterosexual perspective that presents women merely as sexual objects for the pleasure of the male viewer. As Edward Snow in Theorizing the Male Gaze: Some Problem has put it:

When FEMINISM CHARACTERIZES "the male gaze" certain motives are almost sure to appear: voyeurism, objectification, fetishism, scopophilia, woman as the object of male pleasure and the bearer of male lack, etc. Masculine vision is almost invariably characterized as patriarchal, ideological, and phallocentric (30).

From this perspective, the meaning of male gaze rests on two things: it is a manifestation of unequal power between the gazing man and gazed upon woman or an effort to develop gender inequality, on the one hand, on the other, it is to achieve pleasure from woman's body. In this situation, woman becomes "spectacle" and man is "the bearer of the look" (Mulvey 62).

Michel Foucault in his book Discipline and Punish: The Birth of Prison develops the concept of the gaze to illustrate socio-political power relations dynamics. He sees gaze a means of control, and, thus, connected to power and surveillance: the person who gazes is empowered over the person who is the object of the gaze. This power imbalance is the serious concern of art and film critics who claim that Western art and many classic Hollywood films are based on the idea of the male gazer and the female object. Within this context, Linda Nochlin in Women, Art, and Power has addressed the issue arguing that "the male artist's right to represent women is interconnected with the assumption of general male power over and control of women in society (12). 


\section{WOMAN AND BODY}

Exhibition of woman's body in any form of art satisfies male spectator's voyeuristic desires. Her physical symmetry becomes source of enjoyment and pleasure for the male viewers, and enables their sexual excitement. In his influential book Ways of Seeing, John Berger explains the appeal of the female nude to the male gaze: "Her body is arranged in the way it is, to display it to the man looking at the picture. This picture is made to appeal to his sexuality" (55). He also explains how women's response to this gaze is culturally conditioned: "Men survey women before treating them. Consequently how a woman appears to a man can determine how she will be treated. To acquire some control over this process, women must contain it and interiorize it" (46). Thus, gaze can be studied in terms of system of power. It is a cultural hegemony and unequal power dynamics between male and female, and a woman who is subjected to the gaze is her loss of autonomy. In this situation, woman's body becomes an object rather than a subject. When her body is considered as a mute object for incarnation of ideal such as beauty, purity, resurrection and self-sacrifices, it destroys the experience of self-embodiment. As a result, body does not possess the meaning of individuality.

Women's naked body has played significant role since past in any form of art. It has traditionally viewed as innocence and beauty. This play When We Dead Awaken is analyzed as an exposition of fetish pleasure through a woman's body. Professor Rubek uses Irena as a model of his artistic creation through which he achieves world fame as an artist. She is a beautiful girl growing in her youth with robust body. Her beauty, vibrant youth, virginity and innocence become helpful raw materials for his artistic mission. Rubek cherishes the dream of a statue in the form of a young woman's body, and works all hours and puts the finishing touches to his great masterpiece that he calls "Resurrection Day" (I, 227). In her frankness, Irena openly serves him her nakedness. Throughout history, female's naked body has been perpetually center of art in many visual and fictional works. Woman's nakedness in such arts can be taken as the matter of idealistic, pornography or erotic art. In this sense, Irena's naked body carved in that marble statue can be viewed either as ideal or pornography depending on viewers' gazes. For the artist, Rubek it is pure art "the noblest, the purest, the ideal" (I, 246). He says, "Doesn't she look like the embodiment of resurrection?" (II, 262). During depicting her in the statue, he suppresses his carnal desires, and does not touch her because the great task dominated him completely is 'exultant joy'. To him she becomes holy, and if he touched her, or desired her sensually, his vision would be so "desecrated that I should never be able to achieve what I was striving after" (I, 246). In this sphere, Irena in the shape of a beautiful young woman, unsullied and pure is the symbol of Rubek's creative nature and an art for art's sake.

In the male gaze system, woman's body possesses double meaning. Irena's naked body for the spectators' voyeuristic gaze becomes pornography. Many spectators look at her unclothed body as a means of fulfilling their sexual desires in contrast to her artistic institution and Rubek's idealizing intention. Her body portrayed in its nudity becomes sexual allure and source of pleasure for the spectators' voyeuristic desires and fantasies. As Irena claims, "I've posed in music halls, naked on a turntable, as a living statue. I made a lot of money that way... Then I have been with men whose heads I could turn" (I, 242). Exposition of the naked body in many shows for the nineteenth century viewers is equivalent to a table dancer who tried to attract rich and temporary husbands. Thus, Irena's naked statue in living picture the voyeur relates to negative stereotypes of male gaze. But Irena's aim is not to posit her body to the voyeur's degenerate gaze, rather it is her devotion, dedication and sacrifice. She mysteriously alludes to killing all her lovers, every child, even the still born child. She still possesses a sharp dagger to attack those who view her as erotic object. This metaphorical expression of Irena illuminates that her body is not a source of sexual delight or entertainment, but an innovation and pure artistic creation.

\section{GAZE AND ITS EFFECT}

John Berger in his book Ways of Seeing exposes women's predicament under male gaze and surveillance as:

Men act and women appear. Men look at women. Women watch themselves being looked at. This determines not only most relations between men and women but also the relation of women to themselves. The surveyor of woman in herself is male: the surveyed female. Thus she turns herself into an object - most particularly an object of vision: a sight (47).

Irena is the female character who has suffered the same predicament under Rubek's gaze. Rubek's sight linger on the curve of Irena's body. He derives pleasure from looking at Irena, and projects fantasies onto her. Her symmetrical body as a source of his art will help him earn world's fame. Irena is relegated to the status of an object to be admired only for her physical appearance, and under his gaze stands for visual pleasure. Thus, she exists for Rubek, a 
mechanism to serve an artist's ego, his libido, and his sense of possession and property. Being mad in her beauty, the artist chooses Irena as a perfect match of his imaginary woman to carve in a stone statue, a woman "filled with a holy joy at finding herself unchanged in the higher, freer, happier sphere, after the long dreamless sleep of death" (I, 246). Irena, of her own accord, sacrifices her youth and life for Rubek's masterpiece and devotes herself as a friend, his helper and coworker to execute Rubek's artistic ideal. She says: "I held up three fingers to heaven, and swore to follow you to the world's end, and to the end of life. And that I would serve you in all things". She further says, "I fell down at your feet and served you" (I, 245).

Irena's dedication is a crucial part of her existence, but for Rubek she is only a model. The reward of her unconditional sacrifice is Rubek's mere words 'I thank you with all my heart", and "it has been a very happy episode for me" (II, 272). This strikes Irena and hurt her. To him, she becomes a picture of loveliness, and mere model to be used and discarded. He treads her deep love and expectations, and forgets her because he does not need her any more. The beautiful dreams of young woman are obliterated in the name of art. Her body has been exposed in the marble statue as a cheap material to the public who see her naked body to fulfill their voyeuristic desires. However, she calls the statue her 'child', and, like a real mother, undergoes "long pilgrimage" (II, 267), and sacrifices her entire life for the metaphorical child. In order to survive in life, to earn money, she needs to satisfy male's erotic desires and "posed in music halls as a naked statue" (I, 242). Performing the role, she falls into the category of erotic one - an object of the controlling male gaze. She realizes it her death, nemesis and destruction. "The sculpture Rubek", as T. R. Henn observes, "has killed Irena's soul, in the name of art; and in rejecting her he has killed art and life as well" (The Harvest of Tragedy 185). She is nothing significant for him, but a means to his end. (Bekmann)

Professor Rubek, as a voyeur objectifies Irena as a source of pleasure and sole inspiration. She becomes an object of his gaze that positions her as a material through which he dreams to achieve fame as an artist. Thus, Irena's identity as a woman is limited to a beauty object, temporary pleasure and muse. A famous feminist critic Adrienne Rich analyzes: 'When We Dead Awaken' is about the use that the male artist and thinker - in the processor of creating culture as we know it - has made of woman, in his life and in his work; and about a woman's slow struggling awakening to the use to which her life has been put" (qtd. Farfan 65). Rubek is responsible for the death of Irena's life's happiness and dreams. As Ronald
Gray puts: "Rubek has betrayed Irena, betrayed the ideal, by not making love to her when she stood before him naked, as his model. He failed . . . to make the synthesis of the real and the ideal. Irena has perished because of his failing" (190).

But the central irony of the play is that Rubek feels void and dejection in life since he has forfeited Irena. He begins to feel lacking something in life despite his fame, material prosperity, artistic dexterity, and independence. He seems to be dissatisfied with his wife, Maia whom he calls "knife in my heart" (I, 247), and his talent in art. He derives sardonic pleasure from his busts, and his real work also comes to an end: "But I didn't love my own work any longer. All the garlands and the incense only sickened me, and drove me out in despair to hide myself deep in the woods" (I, 259). He turns listless, misanthropic with no love for his work since the completion of his universally acknowledged masterpiece 'The Resurrection Day'. All the pleasures, creativity are meaningless, and masterpiece appears to him naïve and false. To activate previous artistic vision and creativity, he aspires Irena because she got the key to open up the casket where all his sculpture's visions are stored up. Thus, he sees Irena as a symbol of "sacrifice, his calling and life's resurrection whereas his wife Maia stands the prostitution of his art" (Severre, Arestad 122). In Irena's absence, he feels, he cannot carve in usual norms and standard. So he has distorted his art, lost the vision, and degraded the statue with animals' faces.

Rubek resurrects artistic calling in him when he rejoins Irena. To regain his robust conscience he has to abandon his wife and reunion Irena. But, ironically, he finds Irena bereft of previous hope, happiness, enthusiasms and vigor. She does not have the key to open Rubek's casket of artistic vision. There is no possibility of resurrection. In retrospect, their life appears to have been happy in the old days, life was "beautiful on the Lake Taunitz", and yet they had "Let all that lovely life slip away" (III, 274). For them, everything is meaningless and purposeless. Both the dead ones awaken, but feel the death of life's joy and happiness. To Irena "the love that belongs to earthly life, miraculous earthly life, mysterious earthly life - is dead in both of them" (III, 288). However, in spite of despair, they proceed up in the light, and in all its "shimmering glory to hold their marriage feast. The sun may look upon them freely" (III, 289). Irena follows her "lord and master. They first past through the mists and then right up to the topmost peak gleaming in the sunrise. But they are engulfed in an avalanche, and achieve their victory through death. 


\section{IRENA AND HER SELF-GAZE}

When professor Rubek abandons Irena after the completion of his masterpiece, Irena, for the first time in life, critically evaluates her contribution to Rubek is worthless. She sees herself to have become an object to be admired only for physical appearance, not a real self. She realizes the role she has played to make Rubek world's famous artist has become her slavery that men desire in male dominated society. A female character does not have real importance, it is how she makes the male feel or act is the prime importance. Irena feels herself to be spendthrift because she has served the artist her body and soul, and provided all male viewers erotic delights. In her free will she has sold her beauty, life, youth and freedom to the male artist, but, in return, she gets nothing, but only disappointment and dejection. She says, "The strings of my being have broken" (I, 244). Her dreams of life as a young woman have been treaded by Rubek. She expresses her remorse:

But I was a human being, in those days. I had a life to lead too, and a human destiny to fulfil. And I let it all go, you see - gave it up to become servant to you. That was self-murder - a mortal sin against myself - a sin that I can never atone for. . . . I should have brought children into the world, many children - real children, not the kind that are hidden away in tombs. That should have been my vocation; I should never have served you, you poet! (II, 271).

Irena has experienced bitterness of life, and feels empty, soulless and death. As John Smythe says, "Within naturalistic convention, her 'death' would be her state- of mind". But, now, risen from the grave after a "long, deep sleep, filled with dreams" (II, 264). In her sadness, her motherly love to the 'child' turns into hatred, and in revenge and anguish she has crushed their 'child'. Her enigmatic expression regarding her complicity in killing her born and stillborn children, many lovers and husband indicates death of love to human beings. In this sense, if Ibsen's When We Dead Awaken is a "strenuous production involving many exorbitant proclamation of love, hate and suffering" ( John S. Beckmann)

Even she is on the verge of stabbing Rubek on his back with the dagger, but finds him already dead. Irena is beginning to rise from her long repose in a grave vault to charge Rubek with the sin against love. She accuses of Rubek being indifferent to her, her dedication and service, but only transfixed his gaze upon her 'pulsing blood of youth', and naked loveliness without ever touching her. She recalls the past that she willingly and gladly renounced home and family, sold her body and young living soul to Rubek. In her livingdeath, she grows hatred, hatred for the artist who "so lightly and carelessly took a warm, living body - a young human life - and wrenched the soul out of it . . because you needed it to create a work of art" (II, 266). She has never loved Rubek's art, and hated the art in Rubek because in past, when she unclothed herself and stood before him, Rubek stood unmoved, "so unbearably self-controlled and only an artist; not a man" (II, 267). She is filled with remorse for not leading her life to fulfil her dream and destiny. She realizes a mortal sin against her individuality. But the only way for her is to kindle her dead life by celebrating a marriage feast 'up to the promised heights' with her 'master and lord'.

\section{MAIA AND RUBEK: MARITAL CONFLICT}

Marriage for Ibsen was sacred that must be based upon a spiritual communion; mere 'living together' was not a true marriage. "True marriage" in his words, "is partnership and comradeship" (qtd. in Lucas 131). In this play, the marital relationship between Rubek and Maia is not based on spiritual realization and proper understanding. It is Rubek who has chosen Maia as a wife because of his lonely existence, and Maia accepts him to be socially and financially secure. However, both of them cannot experience conjugal happiness with each other. The underlying reason behind conjugal unhappiness is Rubek's own sense of emptiness and hollowness. During the period of apostasy, he has experienced youthful aberration, since he has not found anyone who can rekindle his artistic calling. He has married Maia because he wants to substitute life for art. But, ironically, she lacks proper appreciation and understanding of the qualities of Rubek's art. She does not possesses the power Irena has had. Neither she can share his passion for art, not help generate him the calling.

Rubek is not interested in physical relationship with woman. For him, "The work of art is first, and the flesh and blood second!" (I, 246). The role of woman in his eyes is exclusively in service to the artist, his vocation and mission. As he says, "I must have someone who can complete me fulfil me . . be one with me in all my aspiration" (I, 275), which Maia fails. This dissatisfaction with Maia creates chasm in their marital relationship. Although they have been living together, they cannot experience utmost spousal happiness and satisfaction. Rubek's behavior towards Maia is harsh and inconsiderate. With her Rubek is "unbearably tired and slack and irritable" (II, 261). She is his makeshift or "as a sort of second-best" (I, 258). Restless Rubek is not "able to endure this wretched life much longer", and "can't possibly 
go on living together" (II, 257). Internalizing Rubek's truth, Maia frankly demands divorce from him. She says, "If you want to get rid of me, just say so, straight out - and I'll go at once" (II, 257). She is no longer following Rubek, but the bear hunter, Ulfheim with whom she plans to go up a high mountain 'to see the glory of the world', which Rubek had promised in past. Up in the mountain, when Rubek and Irena meet their death by avalanche, Maia's triumphant song sounds from farther down. In the song, she compares herself with a bird just set free from the prison.

\section{CONCLUSION}

Ibsen's When We Dead Awaken has been thought as an epilogue, a summation of his whole production, his farewell to his creative activity. However, the play shares most dominated themes in his many realistic plays. As he has exposed female world and their destiny in male prerogative society, When We Dead Awaken represents a story of young woman whose life and dreams have been killed by a male artist exposing her naked body to the public as an art object. Among various forms of exploitation of woman, representation of woman's body in nudity is another way of male exploitation of female. Thus, women become a sexual objects to be gazed and enjoyed. Woman's visible body, on the one hand, becomes an object for fulfilling the spectators' voyeuristic desires, and on the other hand, be restricted to the transcendental bonds of idealization. In this environment, a woman lacks proper place in systematic social life. She is evaluated and becomes a subject of much discussion only in terms of her carnal beauty, not in her real self, contribution and sacrifice.

\section{REFERENCES}

[1] Arestad, Sverre. 'When We Dead Awaken' Reconsidered. Scandinavian Studies. Vol. 30, No. 3 (August, 1958) 117-130. JSTOR. Accessed 17/06/2014. http://www.jstor.org

[2] Bekmann, John S. http://prairieuprisingreviews.blogspot.com/2017/05/whenwe-dead-awaken.html. 01 May 2017. Accessed 14 December 2020.

[3] Berger, John. Ways of Seeing. London: BBC and Penguin Books, 1972.

[4] Farfan, Penny. 'From 'Hedda Gabler' to 'Votes for Women': Elizebeth Robins's Early Feminist Critique of Ibsen'. Theatre Journal. Vol. 48, No. 1 (1996) 59-79. JSTOR 20 August 2010. http://www.jstor.org

[5] Gray, Ronald. Ibsen: A Dissenting View. A Study of Last Twelve Plays. Great Britain: W \& J Mackay Ltd., 1977.
[6] Hawthorn, Jeremy. 'Theories of the Gaze'. Literary Theory and Criticism. Patricia Waugh (ed.). New York: Oxford University Press. 2006. 508-518.

[7] Henn, T. R. et al. The Harvest of Tragedy. London: Methune \& Co. 1961.

[8] Ibsen, Henrik. 'When We Dead Awaken'. Trans. Peter Watts. Ghosts and Other Plays. London: Penguin Books Ltd. 1964. 221-290.

[9] Lewis, Ingrid and Irena Sever Globan. 'The New/Old Patriarchal Auteurism: Manoel de Oliveira, the Male Gaze and Women's Representation'. European Cinema in the TwentyFirst Century. Ingrid Lewis and Laura Canning (ed.). Switzerland: Palgrave Macmillan, Cham. 2020. 129-147.

[10] Lucas, F. L. The Drama of Ibsen and Strindberg. London: Cassell \& Com. Ltd., 1962.

[11] Mulvey, Laura. 'Visual Pleasure and the Narrative Cinema'. Visual and Other Pleasures: Theories of Representation and Difference. Indianapolish: Indiana University Press, 1989. 5768.

[12] Nochlin, Linda. Women, Art, and Power: and Other Essays. New York: Harper, 1988.

[13] Raymond, William. Drama from Ibsen to Brecht. London: Chatto \& Windus, 1968.

[14] Schultz, Robert. 'When Men Look at Women: Sex in an age of Theory. The Hudson Review. Vol. 48, No. 3 (Autumn, 1995) 365-387. JSTOR. Accessed. 11/06/2019. http://www.jstor.org

[15] Smithe, John. http://theatreview.org.nz/reviews/review.php?id=9589. 28 September 2016. Accessed. 14 December 2020.

[16] Snow, Edward. 'Theorizing the Male Gaze: Some Problem. Representations. No. 25 (Winter, 1989) 30-41. JSTOR. Accessed: 03/02/2016. http://www.jstor.org

[17] Sturken, Marita and Lisa Cartwright. Practices of Looking: An Introduction to Visual Culture. Oxford: Oxford University Press, 2009. 